Journal of Awareness

Cilt / Volume 5, Sayı / Issue 3, 2020, pp. 325-330

E - ISSN: 2149-6544

URL: https://journals.gen.tr/joa

DOI: https://doi.org/10.26809/joa.5.024

Araştırma Makalesi / Research Article

\title{
CRISIS OF FEMININE IDENTITY: A CRITICAL STUDY OF OSCAR WILDE'S LADY WINDERMERE'S FAN FROM FEMINIST PERSPECTIVE
}

\author{
Dulfqar Mhaibes ABDULRAZZAQ* \& Mohammed Mahmood ABBAS** \\ * Karabuk University/ Faculty of Letters, \\ TURKEY, e-mail:dulfqar@gmail.com \\ ORCID: https://orcid.org/0000-0002-2614-6388 \\ ** Karabuk University/ Faculty of Letters, \\ TURKEY, e-mail: thesecondmohammed91@ gmail.com \\ ORCID: https://orcid.org/0000-0002-8109-9481
}

Received: 31 May 2020; Accepted: 25 July 2020

\begin{abstract}
This study explores the play Lady Windermere's Fan by Oscar Wilde, and the feminist figures in the play and their role, to illustrate the dominant control of men in the Victorian period. And the discrimination towards women as a human being base on gender. This paper shows a piece of brief information about the author for what it has to do with Lady Windermere's fan events. And demonstrates the feminism meaning and its impact on the events of the play, besides a short summary of the play. This paper focuses on the role of the fallen woman and how the author gradually transforms the audience's thinking about the fallen woman and contradicts the conventional view of it. And illustrate the inferiority view of women in the Victorian era and how the woman only meant to be part of domestic life. In addition to the motherhood and how a fallen woman acts with that in Victorian society according to Wilde's point of view.
\end{abstract}

Keywords: Oscar Wilde, Lady Windermere's Fan, feminism, fallen woman, motherhood. 


\section{INTRODUCTION}

There can be no question about that Oscar Wilde considered one of the Iconic authors and critics of his time. Born in 1854 of an Anglo-Irish wealthy family, his father was a successful surgeon and his mother was a poet. she had the greatest influence on him as a write through the storytelling that she tells at a young age, eventually formed Oscar Wilde as a poet and playwright. Later Wilde got a good education at Trinity and Magdalen college, after he graduated from Oxford he settled down in London to establish a literary career and focus on his work as a writer. In London, Wilde has joined the trendy intellectual and literary circles of high society, thus he had access to the world that would be the source for his social criticism. Wilde concentrated on the Victorian culture and satirized its ideals under its own words. (Ellmann, 1988).

Lady Windermere's Fan is a social satire that explores the social standards, attitudes, and mannerisms of the Victorian period. The play about a happy couples-married, lady Windermere and Lord Windermere. Lady Windermere is an innocent trusty girl who gets information that her husband lord Windermere is cheating her with another woman, she doesn't believe that at first but then she suspects her husband. She checked her husband's financial book and find that Lord Windermere spend a large sum of money for a woman called Mrs. Erlynne. Through the dialogue of the play, it is clear that Mrs. Erlynne is lady Windermere's mother who abounded her when she was a child. Lord Windermere invites Mrs. Erlynne to his wife's birthday party, to allow her to reclaim some of her dilapidated social position. Lady Windermere couldn't accept that so she decides to leave her husband a letter telling him that she is going to escape with Lord Darlington. Mrs. Erlynne finds that letter, she runs to Lord Darlington's room to persuade her daughter not to make the same mistake that she did before. Simultaneously, Lord Windermere and Darlington with other men come to the room, Lady Windermere hides behind the curtain but she forgets her fan, and in order not to make Lord Windermere suspect her wife. Mrs. Erlynne sacrifices her reputation and tries to help her by showing up and claim that she took the wrong fan from the party. At the end of the play Lord and Lady, Windermere's marriage saved and decides to take a holiday a way of the society.

During the Victorian society, British colonialism was at its highest point, the trading markets expanded and English culture operated according to strict rules that everyone, his goal to gain money and marrying an aristocratic woman, or try to obtain a higher education. Thus, it was very important to have a good reputation at all times, the scandal should be avoided. In the Victorian era, women were considered to belong to the domestic sphere, and this stereotype forced them to provide a clean home for their husbands, organize meals on the table, and raise their children. In this period, the rights of women were extremely restricted. And women have been forced into a position of dependence on men, thus they had little chance of being financially independent. Also, the rights of women were legally transferred to their spouse when a man and woman get married, and the married couple became a single person represented by the husband according to the law. putting men in charge of all of her possessions, income, and cash. Besides losing all money and lands to their husbands, a woman in Victorian society became their husbands' property, granting them the rights to what was made by their bodies, domestic labor, children, and sex. (Buckner \& Francis, 2005). The realistic comedy style in the Victorian era was a major contribution to highlighting the problems of that period. Especially, the storytelling and dramatic illusion were deeply integrated with the success of many theatres, that had a direct impact on the audience. (Holland, 2007, p. 255).

Lady Windermere's Fan examines discrimination on basis of gender against women, thus feminism theory is about promoting women's rights based on gender equality, this means that women should not be treated differently than men in terms of rights, duties, and privileges. (Walters, 2005). Women's rights advocates in England emerged from the working class, who 
some of them have a socialist tendency. Over time and because of the contributions of the Victorian writers such as Oscar Wilde, and because of the literature is the mirror of society, all this led to a focus on women's rights, even from the men themselves, and this has emerged in modern English theater. (Patterson, 2003, p. 155).

Rita Felski in her book Doing Time: Feminist Theory and Postmodern Culture, examines the patriarchal power in Victorian society on woman "Patriarchal power pervades verbal and visual systems of meaning. Within such systems, a woman is always connected to and inseparable from man. Men's ability to symbolize the universal, the absolute, and the transcendental depends on the continuing association of femaleness with difference, otherness, and inferiority." (Felski, 2000, p. 181). Thus, women supposed only to act as good mothers and wives, and never be inseparable of men socially and financially. Also, unmarried or illegitimate children are deemed to be a social failure in Victorian society.

\section{FALLEN WOMAN}

In Lady Windermere's Fan, Oscar Wilde gives the fallen woman the lead role. According to the Victorians, the term fallen woman means a woman who had a sexual relationship without marriage, or described as a woman who lost her chastity and fell from God's grace, such as prostitutes, unwed mothers, and adulteresses, this was considered unnatural to women's behavior. This kind of women was regarded as deviant and removed from society. Although it was not acceptable for a woman to have sexual relationships outside marriage, while it was regarded as acceptable behavior only for men. The Victorians could not differentiate a prostitute from a woman who commits one mistake only. (Nochlin, 1978). Wilde illustrates that there are two types of women, the innocent one for marriage and the other one used as a sexual object, only for sex. Thus, he satirizes the hypocrisy of Victorian society, which allows men to do everything while if a woman tried to transgressed that will not be tolerated and could be regarded as a threat to the entire system of that era.

Wilde makes the character of Mrs. Erlynne, the central character that plays the double woman, at first, she presented as an immoral lady, who has a sexual relationship without marriage, then the good woman at the end of the play. The others suspect her as a fallen woman, the Duchess of Berwick describe Mrs. Erlynne as "a horrid woman ... absolutely inadmissible to society" (Wilde, 1907, p. 26). Wilde tried to treat this discrimination against the fallen woman through contradiction. When Mrs. Erlynne joins the party, she contradicts the audience's expectations of fallen women. Wilde Characterize her as "very beautifully dressed and very dignified." (Wilde, 1907, p. 58). The reader can clearly notice that Oscar Wilde rejects the notion of a fallen woman from the first scene of the play. Wilde demonstrates another point of how Victorian society considers women inferior to men. They should be live in a restricted sphere and deal the domestic life only, they were excluded from their entire life in all aspects, a wife should only take care of children and put the food on the table and never questioning her husband. (Flanders, 2003). When the Duchess of Berwick visit Lady Windermere and tell her about the infidelity of her husband, Lady Windermere wants to know the truth about that, thus she checks her husband's financial book, but when Lord Windermere knows that her wife searches his book, his respond was angry, "Margaret, you have cut open my bank book. You have no right to do such a thing!" (Wilde, 1907, p. 34). Then he continues saying that "I think it wrong that a wife should spy on her husband." (Wilde, 1907, p. 35). This dialogue is a major factor in the position of women and indicates that a wife should not interfere with her husband's affairs.

Even if the husband has a sexual relationship, the wife should not interfere with that because one of the most important things in Victorian society is appearances. Everyone should act as perfect as possible. For example, when lady Windermere tells the Duchess of Berwick 
that "Windermere and I married for love." (Wilde, 1907, p. 31), the Duchess mock lady Windermere because infidelity is familiar in the Victorian society and acceptable only for men, but in the same time, the wife should ignore it and never compline or interfere with the husband affairs, and live in an illusion that everything is good, and protect her position amongst the society. The Duchess demonstrates that "before the honeymoon was over, I caught him winking at my maid, a most pretty, respectable girl. I dismissed her at once without a character." (Wilde, 1907, p. 31). This statement indicates that the Duchess is cognizant of the infidelity of her husband but at the same time act as if nothing happens, because men regarded superior to women in that era. And that illustrates Wilde's concern about women's unequal situation.

Gail Cunningham in his book, the new woman and the Victorian novel demonstrates that the misconceived notion of a woman in the Victorian period, they were described as children with narrow-minded, "I believe, fancy women's minds something like those of children. Now, that is a mistake." (Cunningham, 1978, p. 42). Lord Windermere, use the same expression when lady Windermere persists to see Mrs. Erlynne, before they leave, "My child, you may be on the brink of a great sorrow. Don't go to meet it." (Wilde, 1907, pp. 130-131). The repetition of Lord Windermere's using the word child illustrates his sense of superiority over her. Thus, he knows more about what she simply needs more than herself as if she has no adult mind, including taking the crucial decision regarding her personal life, without even taking her opinion into his consideration. For example, he didn't tell lady Windermere that Mrs. Erlynne is her real mother, or even let her know that her mother is still alive, he decides that without discussing it with her. Lord Windermere explains that Lady Windermere shouldn't realize that her mother is a fallen woman and keep to believe that she is dead:

But rather than my wife should know - that the mother whom she was taught to consider as dead, the mother whom she has mourned as dead, is living - a divorced woman going about under an assumed name, a bad woman preying upon life, as I know you now to be-rather than that." (Wilde, 1907, p. 135)

Wilde attracts attention to the gender double standard's inequality. The men's reactions after finding Mrs. Erlynne in the room of Darlington indicates the double standard. Consequently, it is acceptable in Victorian society for men to be in other women's rooms but it is disgraceful for a woman to do that. And the reader can observe that when lord Darlington informs Lady Windermere, "I couldn't! A man can't tell these things about another man!" (Wilde, 1907, p. 67). Thus, Mrs. Erlynne is seen with an inferior look, she found in the room of men. And later on, Lord Windermere describes her with a cruel word, telling her that "you are found in a man 's rooms-you are disgraced before every one ... you are-a worthless, vicious woman." (Wilde, 1907, p. 136).

\subsection{Motherhood}

The author demonstrates the rejection of motherhood through the character of Mrs. Erlynne, and consider a central theme in Lady Windermere's Fan. The motherhood considers a highly controversial issue among feminist and anti-feminist. The anti-feminist claimed that women are born to be mothers, and that is their destiny. While feminist contradict with that matter. The female protagonists regarded their motherhood as an unhappy experience and miserable point in their lives, because motherhood was extremely significant in the Victorian era regardless if a woman wants that or not, it is their duty to raise and shape their children's values, and this perspective was conveyed by parents, churches, and schools to young women, just to train and prepare them to be mothers. (Cruea, 2005, p. 188). Oscar Wilde with his wit and revulsion towards Victorian society contradicts all their interpretation of womanhood and defies the audience's assumptions about a fallen woman. Through the character of Mrs. Erlynne 
Wilde, deny the traditional ideas about the fallen woman that must behave like a repentant sinner. For example, lord Windermere tries to get Mrs. Erlynne to repent, and remind her of her innocence when she was young, "It's the miniature of a young, innocent-looking girl with beautiful dark hair." (Wilde, 1907, p. 139), but Mrs. Erlynne respond with an explanation that, "It was done before I was married. Dark hair and an innocent expression were the fashion then, Windermere!" (Wilde, 1907, p. 139), she points out that, there are no differences between what she is now and what she was. In other words, she implies that for lord Windermere there are no two types of women, all humans including women is likely to be mistaken. Mrs. Erlynne mocks the way men think in the Victorian era and their traditional conceptions of a fallen woman by demonstrating that:

I suppose, Windermere, you would like me to retire into a convent or become a hospital nurse or something of that kind, as people do in silly modern novels. That is stupid of you, Arthur; in real life we don't do such things - not as long as we have any good looks left, at any rate. No what consoles one now-a days is not repentance, but pleasure. Repentance is quite out of date. (Wilde, 1907, p. 141)

Wilde tries to present Mrs. Erlynne in a sympathetic way and prevent the audience from assuming that a woman who repudiates motherhood is bad. And incorporating his believes that not all women have to be mothers, it is kind of a personal decision to make, and the society has nothing to do with that. Nevertheless, it was not easy for Mrs. Erlynne to choose freedom and rejects motherhood, she proves that she has feelings for lady Windermere, when she sacrificed her reputation and saved lady Windermere's marriage, but in the same time, Mrs. Erlynne couldn't reveal her true identity for lady Windermere because, obviously telling her that, Mrs. Erlynne is her real mother will destroy everything, "If I lost my ideals, I should lose everything." (Wilde, 1907, p. 146). Lady Windermere has a perfect image of her mother, "We all have ideals in life. At least we all should have. Mine is my mother. (Wilde, 1907, p. 145), out of love, Mrs. Erlynne did not tell the truth. However, the thoughts of Victorian society have a great impact on lady Windermere personality, thus if she knows the truth, she will never get over it.

At the end of Wilde's play did not condemn his fallen woman. Mrs. Erlynne denies the Victorian society, and suffer from the unjust judgments because she is a woman with a past. Wilde seems doesn't mean of making her leave Britain consider as a punishment but, the play end as a happy ending for Mrs. Erlynne, because she turns her back for a hypocritical, narrowminded society, rejecting all the ideas regarding the fallen woman, and win possibly a happy marriage with Lord Augustus.

\section{CONCLUSIONS}

Oscar Wilde offers unexpected illustrations for a fallen woman. He demonstrates the injustice of the Victorian society towards women and fallen woman in particular. And illustrate the ongoing conflict between women and men, and their sphere in the society, in which women are sustain in close clasps between patriarchal society and gender limitations. Thus, any attempt to break the Victorian's standards was seen as a challenge to male dominance sphere and the domestic life of women. Wilde used his wit and intelligence to make the audience sympathize with his fallen woman. Unconventionally, he reverses all the ideas regarding the fallen woman, presenting Mrs. Erlynne as an object of disgrace at first, then moving to an outstanding position. Moreover, Wilde gives her a happy ending with a stable marriage, far from Victorian society. And That was exceptionally unusual with the traditional fallen woman's plays in that period. He also, ridicule the division of Victorian society for people as good and bad. Thus, he contradicts that division through lady Windermere when she considers Mrs. Erlynne as a bad woman at the beginning of the play and believes all rumors about her reputation and declare that, "Arthur, if that woman comes here, I shall insult her." (Wilde, 1907, p. 44). But, at the end 
of the play, lady Windermere dramatically changed, "Ah, you're marrying a very good woman." (Wilde, 1907, p. 155). Wilde, also contradict the Victorian society regarding motherhood, he illustrates that motherhood is not a natural instinct for all woman. Therefore, a woman who refuses the role of mother is not necessarily inferior. Wilde not only satirizes the Victorian society in general and fallen woman in particular but he also criticizes the Victorian concept of woman. He highlights the awful discrimination against women based on their gender.

\section{REFERENCES}

BUCKNER, P., \& Francis, R. (Eds.). (2005). Rediscovering the British World. Canada: University of Calgary Press.

CUNNINGHAM, G. (1978). The new woman and the Victorian novel. London: The Macmillan press ltd.

ELLMANN, R. (1988). Oscar Wilde. New York, NY: Vintage Books.

FLANDERS, J. (2003). The Victorian House: Domestic Life from Childbirth to Deathbed. UK, London: HarperCollins Publishers Ltd.

HOLLAND, P. (2007). Redefining British theatre history. Basingstoke, Hampshire: Palgrave Macmillan.

NOCHLIN, L. (1978). Lost and Found: Once More the Fallen Woman. The Art Bulletin, 60(1), 139- 153. doi:10.2307/3049751

PATTERSON, M. (2003). Strategies of political theatre: post-war British playwrights. New York, NY: Cambridge University Press.

SUSAN M., C. (2005). Changing Ideals of Womanhood During the Nineteenth-Century Woman Movement. The American Transcendental Quarterly, 19(3), 188-204. Retrieved from https://scholarworks.bgsu.edu/cgi/viewcontent.cgi?article=1000\&context=gsw_pub.

WALTERS, M. (2005). Feminism: a very short introduction. New York, United States: Oxford University Press.

WILDE, O. (1907). The writings of Oscar Wilde. New York, NY: J. F. Tapley Co. Printers and Binders. 